International Journal of Food and Nutrition Research
(ISSN:2572-8784)

\title{
Content Analysis of Television Food Advertisements Aimed at Children: Case Study of Lagos and Ibadan
}

\author{
Folake O. Samuel ${ }^{1}$ and Grace O. Ekundayo ${ }^{2}$ \\ ${ }^{1}$ Department of Human Nutrition, University of Ibadan, Ibadan, Nigeria. \\ ${ }^{2}$ Department of Human Nutrition, University of Ibadan, Ibadan, Nigeria.
}

\begin{abstract}
Advertisement is one of the major components of the food *Correspondence to Author: environment which influences in childhood food choices. Grace O. Ekundayo

This study was conducted to analyze the content of food Department of Human Nutrition, advertisements aimed at children in Lagos and Ibadan, Nigeria. University of Ibadan, Ibadan, NigeAdvertisement samples which were aired between March 2016 ria.

to April 2016 were collected from six television stations. A total of 58 advertisments aimed at children were coded and analysed thematically.

How to cite this article:

Beverages, fruit drinks and soft drinks were the most frequently Folake O. Samuel and Grace $O$. advertised (32.8\%). Butter and margarine had the highest mean Ekundayo. Content Analysis of duration of time spent for advertisement (47.00 22.91 seconds), Television Food Advertisements while the mean time for all the advertisement was 34.72 \pm 14.05 Aimed at Children: Case Study of seconds. Although $82.8 \%$ of the advertisements had a slogan, about half of them (48.3\%) carried no nutrition message.

Lagos and Ibadan. International Journal of Food and Nutrition Research, 2018; 2:16.

Keywords:

Food advertisement, nutrition claims, children, Nigerian Television.

eScî̀Pub

eSciPub LLC, Houston, TX USA.

Website: http://escipub.com/
\end{abstract}




\section{INTRODUCTION}

Media, especially television provides information that can reach a large population at the same time since it is available and watched by a vast number of individuals. The television is a powerful medium for marketing and advertising products (1). It has long been recognised that the media's reach and prevalence in every day life makes it a natural expansion of people's interpersonal network. This implies that the media influences and encourages conversation topics among friends and family that further shape individual perspectives (2) . Television advertisements usually appear between shows, but also interrupt the programme at intervals. This method is used to capture the attention of the audience and keep the viewer focused on the television shows so that the channel will not be changed as they patiently watch the advertisement while they wait for the next segment of the programme. This technique adds suspense, especially if the break occurs at a cliff hanger moment in the show (3). In most developing countries, television is increasingly becoming a good medium to advertise to a large audience. Globalization has resulted in greater variety, availability and diversity of food and this has led to an increase in food products in the market, no doubt, competitions has intensified. Consequently, consumers are becoming savvy and selective in their decision when purchasing. Persuasive messages are then used by marketers to increase consumer's motivation. Television food advertising employs innovative and compelling strategies to attract viewers and influence product recognition. Therefore, it is possible that the popularity of a celebrity who is featured in the advertisement suggest that the audience's personal preferences and tastes can influenced. Marketers are attracted to the child market because of their strong inflence on family buying decisions and it offers marketers gain the opportunity to gain a life time customer (4). Owing to these facts, companies therefore invest more in their advertisements as children are life consumers of their product. It was estimated that in the United States, annual expenditure of food industry could reach up to $\$ 2.3$ billion in advertisements $(5 ; 6)$.

Television viewing and advertisement is a contributing factor to obesity in children as it reduces physical activity, promotes consumption of snacks, sweetened beverages and fast foods $(7 ; 8 ; 9)$. Though most of the television commercials are usually 30 seconds in length, children are exposed to the behaviour and attitudes of television characters in programs for much longer periods (10). Childhood obesity has become a grave public health problem and growing evidence has shown that obese children will eventually grow to become obese adults with related health consequences especially non communicable disease and increased mortality in adulthood $(11 ; 12 ; 13 ; 14)$. Numerous studies have shown the association between the number of hours spent for food advertisements on television and the prevalence of obesity $(7$; 15). Television advertising contributes to childhood obesity by an estimated $16-40 \%$ in the USA, 10-28\% in Australia and Italy and 4$18 \%$ in Britain (15). However, there are few studies in food advertising aimed at children on television in Nigeria. The Nigerian broadcasting commission stated that 37.3 million households in Nigeria have access to television (16). Such a large viewership is significant as it the television often occupies a central point in many homes. Many homes have arranged their furniture, meals and conversation around the television set (17). In Nigeria, where a prevalence 18\% obesity and $11.4 \%$ overweight among school aged children has been reported $(18 ; 19)$. It is not known what contributing factors food advert may be contributing. Since poor nutritional behaviours in childhood have been found to contribute to chronic health problems in adulthood (20) and these poor nutritional behaviours are usually imbibed from the media (21), it is imperative to analyse the content of television food advertisement aimed at children. Though studies have revealed that children's television programs feature considerably more 
unhealthy foods compared with shows targeting youths and adults (22), the frequency of how these foods are presented should be determined. It is therefore necessary to explore the content of food advertisements aimed at children in some television stations in Nigeria.

\section{METHODOLOGY}

\section{Data Collection}

Video clips of advertisements aired for 31 days between March and April 2016 were obtained from five television stations in Lagos and Ibadan, South Western Nigeria. Data was collected on the number of food-related TV advertisements; time allocated to each advert and the content and approach used by advertisers to market their products.Children-targeted advertisements, in the context of this study are those which are designed on the basis of visual and auditory cues, including the presence of child actors or narrators, verbal appeals to a child audience and the presence of products marketed specifically to children. The selected advertisements in this study were those that featured children less than 13years. This age group may possess money and freedom to purchase food especially at school, and may have linguistic skills to persuade parents to buy foods advertised on television (23).

\section{Data Analysis}

Advertised foods were coded into six groups namely: Beverages/ fruit drink/ soft drinks, Pasta/cereals, Dairy and dairy products, Butter/magarine, Boullion cubes and Convenience/fast foods.

Features of advertisements were coded in several ways; the description of the nutrition claim as verbal or visual nutrition-related messages in the advertisements were coded as low fat/no cholesterol, rich in fiber, vitamins or minerals, low in sodium, natural, low in calories/ energy giving. The human characters (both children and adults) in each advertisment were coded according to their sex, ethnicity, whether characters were shown eating, and the eating location (coded as home, in a restaurant, in a car, outside, or elsewhere). The meal timing was coded as breakfast, lunch, dinner, snack, or nondiscernible. If multiple eating locations or times were depicted, the one with the longest duration was recorded. The inclusion or non-inclusion of a slogan at the end of the advertisement was also coded. Duration of advertisement of the various food groups (in seconds was measured).

Nutrient content of all advertised products were extracted from nutrition facts labels of the advertised foods obtained by visiting grocery stores and company websites. Data collected from the nutritional fact labels include serving size ( $\mathrm{g}$ or $\mathrm{mL}$ ),servings per container, calories (kcal), calories from fat, total fat $(\mathrm{g})$, saturated fat (g), cholesterol (mg), sodium (mg), carbohydrate $(\mathrm{g})$, fiber $(\mathrm{g})$, sugar $(\mathrm{g})$, protein $(\mathrm{g})$; sodium, carbohydrate, fiber; vitamin A, vitamin $\mathrm{C}$, calcium and iron.

\section{RESULTS}

\section{Types of Advertisments aired}

A total of 58 advertisments were obtained from six (6) television stations in the cities of Ibadan and Lagos, southwestern Nigeria over the study period. The distribution of different food groups obtained from the advertisements showed that beverages/ fruit drink/ soft drinks were the most frequently advertised (32.8\%), followed by convenience food/fast foods (24.1\%) and dairy foods $(17.2 \%)$. Others include bread/cereals $(10.3 \%)$, boullion cubes $(8.9 \%)$ and butter/magarine (6.9\%). There was no representation of fruits and vegetables, meats, poultry and fish.

\section{Features of the Advertisments}

Adults and children appeared together as presenters of the main characters in many of the advertisements (41.4\%). Six of the advertisements did not have human presenters at all $(10.3 \%)$. Both males and females featured in the advertisements. Local (Nigerian) characters occupied the majority of the roles (77.6\%). Most of the food advertisements had no specific meal timimg, thoughfoods advertised as snacks featured prominently (24.1\%). 
Table 1: Features of advertisements

\begin{tabular}{|c|c|c|}
\hline Feature & Frequency & Percentage \\
\hline \multicolumn{3}{|l|}{ Presenters of Advertisement } \\
\hline Both Adults and Children & 24 & 41.4 \\
\hline Children alone & 18 & 31.0 \\
\hline Family & 4 & 6.9 \\
\hline Celebrities and Children & 4 & 6.9 \\
\hline Animation Cartoon Characters & 1 & 1.7 \\
\hline $\begin{array}{l}\text { Mixture of Children \& Animation Cartoon } \\
\text { Characters }\end{array}$ & 1 & 1.7 \\
\hline No human presenters & 6 & 10.3 \\
\hline \multicolumn{3}{|l|}{ Sex of presenters } \\
\hline Males only & 9 & 15.5 \\
\hline Females only & 9 & 15.5 \\
\hline Both males and females & 34 & 58.6 \\
\hline None & 6 & 10.3 \\
\hline \multicolumn{3}{|l|}{ Ethnicity of presenters } \\
\hline Local (Nigerian) & 45 & 77.6 \\
\hline Foreign (Caucasian) & 2 & 3.4 \\
\hline Both local and Foreign & 4 & 6.9 \\
\hline Not discernible & 7 & 12.1 \\
\hline \multicolumn{3}{|l|}{ Meal timing } \\
\hline Breakfast & 9 & 15.5 \\
\hline Lunch & 10 & 17.2 \\
\hline Dinner & 6 & 10.3 \\
\hline Snack time & 14 & 24.1 \\
\hline No specific meal occasion & 19 & 32.7 \\
\hline
\end{tabular}

Nutrition messages/claims and slogans in the advertisements

As shown in Table 2, most of the advertisements did not feature any nutrition-related messages
(48.3\%). For those with nutrition messages, the emphasis was on the vitamin and mineral content of the foods, followed by their natural ingredients. There was usually a slogan at the end of each advert (82.8\%). 
Table 2: Type of nutrition messages and slogans in the advertisements.

\begin{tabular}{|l|l|l|}
\hline Variable & Frequency & Percentage \\
\hline Nutrition Messages & 28 & 48.3 \\
\hline None & 17 & 29.3 \\
\hline Vitamins and minerals & 9 & 15.5 \\
\hline Natural ingredients & 9 & 5.2 \\
\hline Low fat & 3 & 1.7 \\
\hline Energy-giving & 1 & \\
\hline Slogans used in the advertisement & 17.2 \\
\hline No & 10 & 82.8 \\
\hline Yes & 48 & \\
\hline
\end{tabular}

\section{Duration of advertisements}

Average duration of all the advertisements was $34.72 \pm 14.05$ seconds (Table 3) Advertisement for the butter/magarine food group had the highest mean time of $47.00 \pm 22.91$ seconds per airing slot.. Beverages/ fruit drinks/ soft drinks had the lowest mean time of $30.74 \pm 10.80$ seconds.

Table 3: Duration of advertisements per airing slot

\begin{tabular}{|c|c|c|c|}
\hline Food group & Frequency & $\begin{array}{c}\text { Mean } \\
\text { (seconds) }\end{array}$ & $\begin{array}{c}\text { Standard } \\
\text { Deviation }\end{array}$ \\
\hline Butter/magarine & 4 & 47.00 & 22.91 \\
\hline Boullion cubes & 5 & 43.60 & 13.79 \\
\hline Bread/Cereal/Grains & 6 & 38.00 & 7.97 \\
\hline Convienience foods & 14 & 33.29 & 14.99 \\
\hline Dairy & 10 & 33.00 & 15.48 \\
\hline $\begin{array}{c}\text { Beverages /soft drinks/fruit } \\
\text { drinks }\end{array}$ & 19 & 30.74 & 10.80 \\
\hline Total & 58 & 34.72 & 14.050 \\
\hline
\end{tabular}

\section{Nutrient Content of Advertised Foods}

Table 4 shows the nutrient content of all the advertised products as shown by the food labels. The average serving size for all foods in this study was $98 \mathrm{~g}$ (range 70 - 100), with an average of 358.93 calories $(\mathrm{kcal}) /$ serving (range, 42-894) of which carbohydrate was $37.52 \mathrm{~g}( \pm 28.84)$, protein was $7.99 \mathrm{~g}( \pm 6.58)$ and total fat was $13.60 \mathrm{~g}( \pm 21.72)$. Fat soluble vitamins $A$ had a mean of 2122.77IU ( \pm 6238.56$)$, Vitamin D had a mean of $40.20( \pm 99.15) \mu \mathrm{g}$, Vitamin $\mathrm{E}$ had a mean of $4.22( \pm 9.95)$ IU and Vitamin K had a mean of $1.45( \pm 3.81) \mu \mathrm{g}$. Of all the water-soluble vitamins, Vitamin B3 had the highest mean of 
Folake O. Samuel and Grace O. Ekundayo, IJFNR, 2018; 2:16

$4.96 \pm 9.10 \mathrm{mg}$ while vitamin B5 had the lowest fact labels. Iron had a mean of $8.34 \pm 15.40 \mathrm{mg}$, mean of $0.98 \pm 2.70 \mathrm{mg}$ among the Vitamin B Calcium had a mean of $135.19 \pm 255.06 \mathrm{mg}$, complex. Vitamin $C$ had a mean of $10.79 \pm 24.67$ lodine had a mean of $163.09 \pm 768.25 \mu \mathrm{g}$ and $\mathrm{mg}$. Minerals were also present in the nutritional Sodium had a mean of $1167.98 \pm 4530 \mathrm{mg}$.

Table 4: Nutrient Content of Advertised Foods (average)

\begin{tabular}{|c|c|c|}
\hline Nutrients & Mean & Standard Deviation \\
\hline Energy & $358.93 \mathrm{kcal}$ & 209.54 \\
\hline Carbohydrate & $37.52 \mathrm{~g}$ & 28.84 \\
\hline Protein & $7.99 \mathrm{~g}$ & 6.58 \\
\hline Total fat & $13.90 \mathrm{~g}$ & 21.72 \\
\hline Saturated Fat & $5.87 \mathrm{~g}$ & 10.0 \\
\hline Cholesterol & $0.04 \mathrm{~g}$ & 0.19 \\
\hline Fibre & $1.5 \mathrm{~g}$ & 2.25 \\
\hline Vitamin A & $2127.77 \mathrm{IU}$ & 6238.54 \\
\hline Vitamin B1 & $1.89 \mathrm{mg}$ & 4.35 \\
\hline Vitamin B2 & $1.31 \mathrm{mg}$ & 2.62 \\
\hline Vitamin B3 & $4.96 \mathrm{mg}$ & 9.10 \\
\hline Vitamin B5 & $0.98 \mathrm{mg}$ & 2.70 \\
\hline Vitamin B12 & $1.62 \mathrm{mg}$ & 2.12 \\
\hline Vitamin C & $10.79 \mathrm{~g}$ & 24.67 \\
\hline Vitamin D & $40.20 \mu \mathrm{g}$ & 99.15 \\
\hline Vitamin E & $4.22 \mathrm{IU}$ & 9.95 \\
\hline Vitamin $\mathrm{k}$ & $1.45 \mu \mathrm{g}$ & 3.81 \\
\hline Sodium & $1167.98 \mathrm{mg}$ & 4530.13 \\
\hline Iron & $8.34 \mathrm{mg}$ & 15.40 \\
\hline lodine & $163.09 \mu \mathrm{g}$ & 768.25 \\
\hline Calcium & $135.19 \mathrm{mg}$ & 255.06 \\
\hline
\end{tabular}

\section{DISCUSSION}

In this study, all the advertised foods targeted at children were processed foods. The food groups that featured in the advertisements include beverages/ fruit drink/ soft drinks, pasta/cereals, dairy and dairy products, butter/magarine, convenience/fast foods and buillion cubes. In comparison to MyPlate - the commonly used food guide with five food groups and their relative proportions arranged in a plate (figure 1), it can be observed that products in the protein as well as vegetables group were missing in 
children's foods adverts. However the grains were represented by pasta and cereals while fruit were only represented in the beverages adverts. Fruit drinks and soft drinks do not count as fruit portions in dietary guidelines.

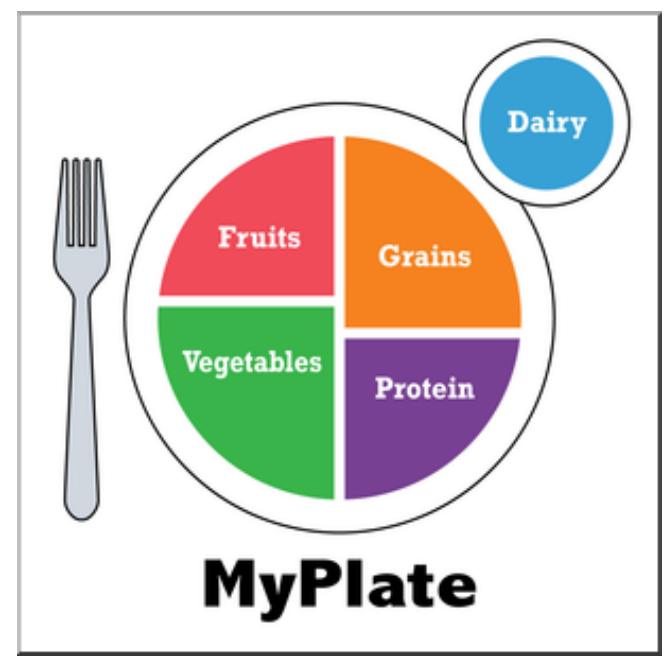

Source: U.S. Department of Agriculture. https://www.choosemyplate.gov/kids Washington, DC. Accessed September 5, 2018.

High level of consumption of sugary drinks (24), convenience foods (25) and confectionery products (26) have been linked to increased body mass index amongst children. Also, advertisements influence children's food choice via their purchase request to their parents and consumption $(27,28)$. In a previous study in South Africa, parents believed that television advertisement do affect their children's nutritional choices as children prefer unhealthy foods such as snack foods which makes it less likely that the children will eat nutritious meals (4).

Most of the advertised food products had no nutrition message but there were few nutritionrelated messages, possibly because children are likely to be more concerned with a food's flavors, taste and colours than its nutrient giving characteristics. The most common nutritionrelated message in this sample was that the advertised product contains vitamins and minerals and some natural ingredients. This information can easily be verified by consumers, and it can be used to decide whether the product meets their own dietary standards. The nutrition messages in food advertisement is important as the information offered in the food advertisements has an effect on food choice and preference which also can affect their nutritional status $(29,30)$.

Most of the characters used were Nigerians, and attempted to depict how a well nourished Nigerian child looks like. The use of Nigerian children and adults in the advertisements aims to establish that the product is essential for the Nigerian child. The strategies used by advertisers in the Nigeria television media are similar to those seen in other studies $(31,32,33$, in that they include persuasive appeals and themes that target more than one sensory mode, namely vision and auditory modes. In this study the advertisers used a mixture of personalities, such as celebrities, adults and children, children only and cartoon characters, to advertise food products. Adults with children were mostly used by the advertisers and this may be due to the knowledge that parents have an important role in children's acquisition of consumer knowledge and skills. It is also well known that celebrities in advertisement may popularise a product since children tend to idolize and respect them. The majority of advertisements that used celebrities in this study were beverages and dairy products using popular sportsmen and having male children as their target. These food products are said to provide essential nutrient and vitality needed for physical activities and sporting games.

Most of the advertisements in this study had slogans at the end of the advert. Advertisements for drinks in the study also contained depictions of intense pleasure sensations, taste and fun. A study found out that children who recognise characters, logos and slogans from advertisements have been shown to be more likely to select those products and brands when they see them (34). Visual familiarity is a key concept in children's decision to try a novel food item (35). Since brief exposure to television food advertisement can influence children food preferences (36), then children's preference for 
these advertised products may be significantly influenced.

\section{Limitations of study}

Data collection was collected within a month and this sample of advertisements may not depict the advertisement shown throughout the year. In addition, the viewing hours and the number of times the children are exposed to these advertisement was not captured in this study. These call for futher research as they could have important inputs into policy-making targeted at advertising to children in Nigeria.

\section{Acknowlegements}

The study grant awarded by DUFIL Prima Foods Plc, Lagos, Nigeria is gratefully acknowledged.

\section{REFRENCES}

1. Guran T, Bekeret A. International epidemic of childhood obesity and television viewing. Minerva Pediatr, 2011; 63: 483-490.

2. Bandura, A. Health promotion by social cognitive means. Health Education \& Behavior, 2004; 31(2) :143-164.

3. Udochi Ukaegbu. Influence of television food advertising on consumer buying habits of Guiness Stout in Ikeja community of Lagos state: Bachelor of Science dissertation Caritas University, Enugu, 2013.

4. Da Fonseca . South African parents' perception of television food advertising directed at children. Masters Business Administration Mini-Dissertation North West University, Potchefstroom Campus, 2010.

5. Millstone E\& Lang T. The atlas of food. London (UK): Earthscan Books, 2002.

6. Investopedia. A look at Coca-Cola's Advertising Expenses(KO,PEP).http://www.investopedia.com. /articles/markets/081315/look-cocacolasadvertising-expenses.asp

7. Andreyeva T, Kelly IR, Harris JL. Exposure to food advertising on television: association with children's fast food and soft drink consumption and obesity. Economics and human Biology, 2011; (9): 221-233

8. Harris, Jennifer L., Schwartz, Marlene B., Brownell, Kelly D. Marketing foods to children and adolescents: Licensed characters and other promotions on packaged foods in the supermarket. Public Health Nutrition, 2010; 13(3) :409-417.

9. Zimmerman FJ, Bell JF. Association of television content type and obesity in children. Am J Public Health, 2010; 100 :334-340.

10. Culp, Jennifer, Bell, Robert A. \& Cassady, Diana. Chracteristics of food industry web sites and "advergames" targeting children. Journal of Nutrition Education and Behavior, 2010; 42(3) :197-201.
11. Centers for Disease Control and Prevention. Basiccs about childhood obesity.http://www.cdc.gov/obesity,childhood/baci cs.html. Accessed May 17,1018.

12. Simmonds M, Llewellyn A, Owen CG, Woolacott N. Predicting adult obesity from childhood obesity: a systematic review and meta-analysis. Obes Rev, 2016; 17(2): 95-107.

13. Puhl RDL \& Janet. Stigma, Obesity, and the Health of the Nation's Children. Pyschological Bulletin, 2007; 113 (4): 557-80.

14. Freedman DS, Kettel L, Serdula MK, Dietz WH, Srinvisan SR, Berenson GS. The relation of childhood BMI to adult adiposity: the Bogalusa Heart Study. Pediatrics, 2005; 115:22-27.

15. Goris JM, Petersen S, Stamatakis E. Television food advertising and the prevalence of childhood overweight and obesity: a multicountry comparison. Public health, 2010;13: 1003-1012.

16. The cable. Only 37 million households in Nigeria have access to television.www.the cable.ng 2015

17. Byrd- Bredbenner C. Saturday Morning Children's Television Advertising: A Longitudinal Content Analysis. Family and Consumer Sciences Research Journal, 2002; 30 (30): 382-403

18. Senbanjo, IO (2010). Overweight and Obesity in Nigerian Preschool Children. Journal of Tropical Paediatrics, 2010; 53 (2): 143-144.

19. Ene-Obong, H, Ibeanu, V, Onuoha, N, Ejekwu . A Prevalence of overweight, obesity, and thinness among urban school-aged children and adolescents in southern Nigeria. . Food Nutr Bull, 2012; 33(4): 242-250.

20. Craigie, Angela M., Lake, Amelia A., Kelly, Sarah A., Adamson, Ashley J., \& Mathers, John C. Tracking of obesity-related behaviours from childhood to adulthood: A systematic review.Maturitas, 2011; 70(3) :266-284.

21. Boyland EJ, Kavanagh-Safran M, Halford JC. Exposure to healthy fast food meal bundles in television advertisements promotes liking for fast food but not healthier choices in children. $\mathrm{Br} \mathrm{J}$. Nutr, 2015;113(6):1012-8. doi: $10.1017 /$ S0007114515000082.

22. Zandile J, MchizaNorman J Temple, Nelia P Steyn, Zulfa Abrahams and Mario Clayford. Content Analysis of television food advertisement aimed at children and adult in South Africa. Public Health Nutrition, $2013 ; 1$

23. Harrison K, Marske AL. Nutritional Content of Advertised During the Television Programs Children Watch Most 2005. American Journal of Public Health, 2005; 95(9): 2

24. Ustjanauskas AE, Harris JL, Schwartz MB. Food and beverage advertising on children's website. International Association for the Study of Obesity. Paediatric Obesity, 2013;(9): 362-367

25. Burgoine T, Forouhi NG, Griffin SJ, Wareham NJ, Monsivais $P$. Associations between exposure to takeaway food outlets, takeaway food consumption, and body weight in Cambridgeshire, UK: population based, cross sectional study. BMJ, $2014 ; 348$. 
26. YH JYK. Factors Influencing Obesity among Adolescent : Analysis of 2011 Korean Youth Risk Behavior Survey. Korean Journal Obesity, 2013; 22(1): 39-49.

27. Christopher $\mathrm{T}$, Lucie $\mathrm{H}$, Robert $\mathrm{P}$, Fiona $\mathrm{T}$, Gillian $R$, Jyotsna V. 10 Years On: New evidence on TV marketing and junk food eating amongst 11-19 year olds 10 years after broadcast regulations. 2018.

28. Mohammad RN, Md Salleh Bin Hj Hassan, Saadat Parhizkar, Musa Bin Abu Hassan. Correlations between children's television advertising exposure and their food preference. Journal of Media and Communication Studies, 2011; 3(8):263-268.

29. Boyland EJ, Nolan S, Kelly B (2016). Advertising as a cue to consume: a systematic review and meta-analysis of the effects of acute exposure to unhealthy food and non-alcoholic beverage advertising on intake in children and adults. Am J Clinical Nutrition, 2016; 103(2):519-33.doi 10.3945

30. Boyland EJ, Whalen R. Food advertising to children and its effects on diet: review of recent prevalence and impact data. Pediatr Diabetes, 2015; 16(5): 331-7.

31. Oyero O, Salawu A. A Thematic Analysis of Children's Food Commercials on Nigerian TV Stations .J Communication, 2014; 5(2): 85-94

32. Dijkstra M, Heidi EJJM, Buijtels W. Separate andjoint effects of medium type on consumer responses: acomparison of television, print and the internet. J Bus Res, 2005; 58; 377-386.

33. Lear KE, Runyan RC , Whitaker WH. Sports celebrityendorsements in retail products advertising. Int J RetailDistrib Manage, 2009; 37 :308-321.

34. Batada A, Borzekowski DLG. Crackley what? Recognition of cereal advertisements and understandingof commercials' persuasive intent amonglow-income, minority, urban youth. J Child Media, 2008; 2: 19-36.

35. Aldridge, Victoria, Dovey, Terence M., Halford, Jason C. G. The role of familiarity in dietary development. Developmental Review, 2009; 29(1): 32-44.

36. Borzekowski, D. The 30-second effect an experiment revealing the impact of television commercials on food preferences of preschoolers. Journal of the American Dietetic Association, 2001; 101(1): 42-46. 